\title{
THE LIMNOLOGY OF THE LAKE TANGANYIKA SUB CATCHMENT
}

\author{
HH Nkotagu and CB Athuman \\ Geology Department, University of Dar es Salaam, \\ P.O. Box 35052, Dar es Salaam, TANZANIA.
}

\begin{abstract}
A limnological study covering the Lake Tanganyika sub catchment was conducted during the dry season at 20 accessible sites on 8 rivers, 2 lakes and a dam. Standard methods were used to determine the levels of abiotic parameters from water samples. Physical parameters including $E C$, Eh, turbidity, temperature, $p H$ and secchi transparency were measured in situ while chlorophyll a was determined in the laboratory. Nutrients such as $\mathrm{NO}_{3}^{-}, \mathrm{SiO}_{2}, \mathrm{PO}_{4}^{3-}$ and $\mathrm{Fe}^{2+}$ were determined along with $\mathrm{HCO}_{3}$. Significant changes in the levels of the abiotic parameters and nutrients have been observed at various sampling sites throughout the study area. The mean variation of $\mathrm{NO}_{3}^{-}, \mathrm{SiO}_{2}, \mathrm{PO}_{4}^{3-}$ and $\mathrm{Fe}^{2+}$ concentrations with depth ranged from 0.4 to $2.6 \mathrm{mg} \mathrm{l}^{-1}$, 2.7 to $35.3 \mathrm{mg} \mathrm{l}^{-1}, 0.01$ to $0.16 \mathrm{mg} \mathrm{l}^{-1}$ and from $<0.010$ to $0.020 \mathrm{mg} l^{-1}$ respectively for the entire sub catchment. Data conclude that processes including dissolution, diffusion, adsorption, absorption, nitrification, denitrification, mixing and reduction along with the anthropogenic activities and increased photosynthetic activity of algae contribute to the variation of the abiotic parameters. It is recommended that quantification of river flows, sediment load and nutrient budget at various sampling points be determined seasonally for proper evaluation of the limnological functioning of the ecosystem.
\end{abstract}

\section{INTRODUCTION}

The limnology of tropical rivers and lakes along with dams has recently received a paramount and growing attention due to pressures from land, atmospheric, and riverine inputs. The Lake Tanganyika sub catchment includes the Malagarasi Moyowosi wetland ecosystem in the Western Tanzania, a polymictic freshwater ecosystem designated as first Tanzanian Ramsar site and the world's $1024^{\text {th }}$ Ramsar site since 2000 (Nkotagu and Ndaro 2004). It is estimated that during the last ten years the depth of the wetland has systematically been reduced to a maximum of about $2 \mathrm{~m}$. The wetland is located in western Tanzania about $200 \mathrm{~km}$ NE of Lake Tanganyika (Fig. 1) The wetland is characterized with biodiversity including varieties of flora and fauna such as fish of which 50 species are known with some being endemic, crocodiles, hippopotamus and other microorganisms (Nkotagu and Ndaro 2004).

These rivers and swamps support the life of many people and other organisms within the Lake Tanganyika sub catchment and hence form a unique ecosystem. However, very little is known on the limnology of this sub-catchment is known.

Present information available on the limnology of the Lake Tanganyika catchment is only the temporal abiotic determinations conducted by Langenberg $e t$ al. (2003). This study focused at the confluence point of the Malagarasi River among others with the Lake Tanganyika at the Delta and concluded that, the external loading forms the main pathway for nutrients entering productive layers of the Lake Tanganyika during stratified and oligotrophic periods.

The present study aimed at identifying causes of changes in abiotic parameters from various surface water bodies including rivers, lakes and a dam in the Lake Tanganyika sub catchment as observed at various accessible points.

\section{MATERIALS AND METHODS}

Study area

The study was conducted for six weeks during the dry season commencing September to October 2004. The study covered the rivers Igombe, Lugufu, Luiche, 
Makere, Malagarasi, Moyowosi, Ruchugi, and Ugalla together with lakes Sagara and Nyamagoma as well as the Igombe Dam within the eastern side of the Lake Tanganyika catchment at the following sites 1 to 20 as shown on figure1. 1=Malagarasi River at the Delta, 2=Malagarasi River at the Ilagala Ferry, 3=Luiche River at the Kigoma-Kasulu Bridge, 4=Luiche River at the Delta in Ujiji, 5=Lugufu River at Jackobsen's Farm, 6=Ruchugi River at the Kigoma-Uvinza Bridge, 7=Malagarasi River at the Nyanza Salt Mine, 8=Malagarasi River at the Uvinza-Mpanda Bridge,
9=Malagarasi River at the Uvinza-Nguruka Bridge, $10=$ Lake Sagara at Amerika, 11=Ugalla River at Katumba, 12=Moyovosi River mouth at the Lake Nyamagoma, 13=Igombe River at Mtega in Kaliua, 14=Igombe River at Uyowa in Urambo, 15=Igombe Dam in Tabora, 16=Moyovosi River at the Kagera-Kigoma Bridge, $17=$ Malagarasi River at the Kasulu-Kibondo Bridge, 18=Makere River at the Bridge,19= Malagarasi River at the Burundi-Tanzania Border and $20=$ Malagarasi River at the Igamba Water fall.

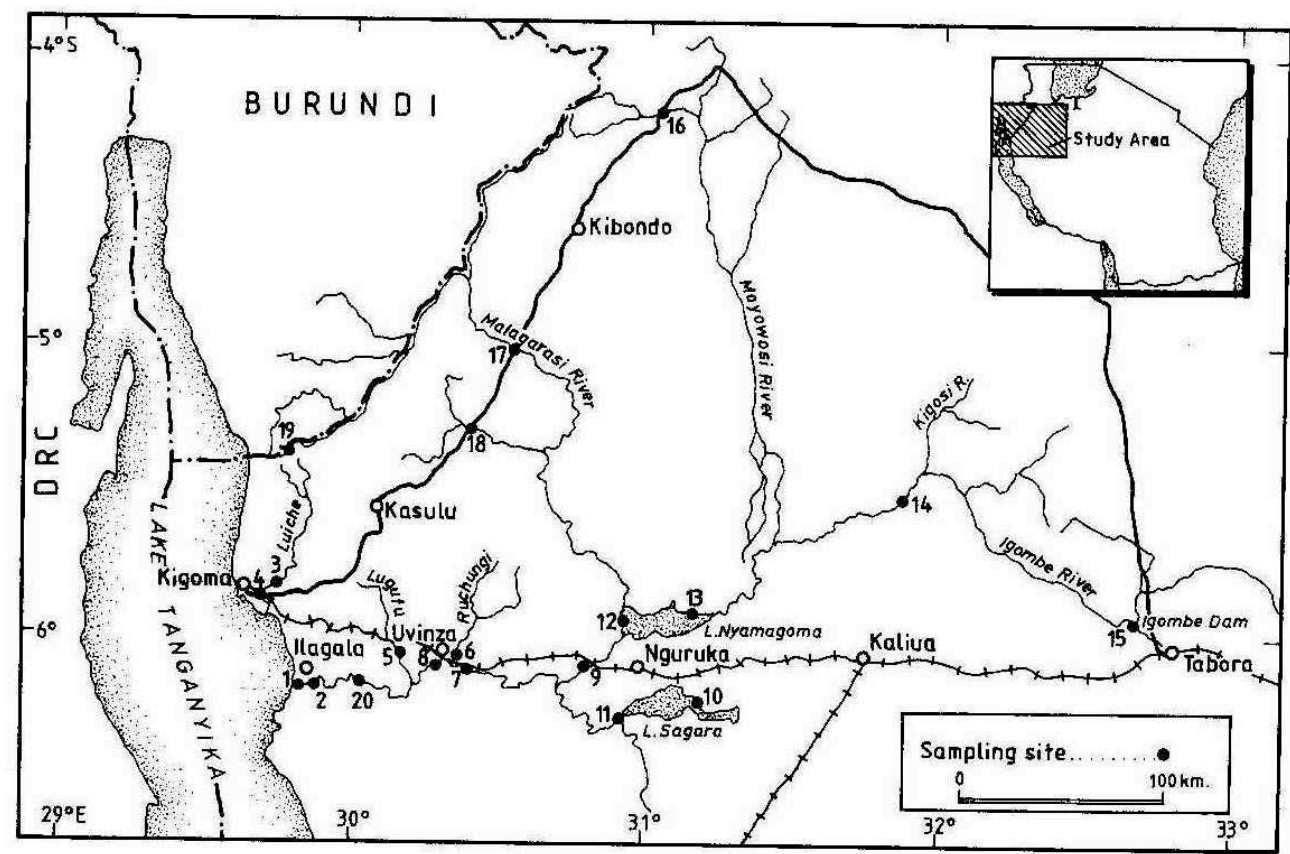

Figure 1: The Lake Tanganyika sub catchment showing the sampling sites

\section{Sampling}

Sampling sites were initially decided basing on water depths as measured at various positions on the rivers, lakes and the dam using a SCUBA device. Water samples were collected by a 2-1 water sampler at selected depth intervals up to maximum depths in half and one-litre plastic bottles filled to the brim. However, at some rivers, sampling was conducted in a horizontal transect across the river at three positions including the centre, right and left banks.

Aliquots of $400 \mathrm{ml}$ and $800 \mathrm{ml}$ of each water sample were filtered using pore size glass fibre $47 \mathrm{~mm}$ size filter papers. The filtrate aliquots were transported on ice to the laboratory for Silica $\left(\mathrm{SiO}_{2}\right)$, Nitrate 
$\left(\mathrm{NO}_{3}{ }^{-}\right)$, Phosphate $\left(\mathrm{PO}_{4}{ }^{3-}\right)$ and Iron $\left(\mathrm{Fe}^{2+}\right)$ determinations. The remaining unfiltered water samples were similarly transported to the laboratory for alkalinity determination.

Filters were placed into a test tube on to which $10 \mathrm{ml}$ of $90 \%$ ethanol were added. The test tubes were then wrapped with aluminium foil, marked and stored overnight in a cooler at $4{ }^{\circ} \mathrm{C}$ ready for chlorophyll $a$ readings the following day.

In situ physical parameters including electrical conductivity (EC), dissolved oxygen (DO), $\mathrm{pH}$ and temperature were measured at each sampling site using a
Multi probe meter 340i model. In addition, turbidity and water transparency were also measured using a $\mathrm{HACH}$ turbidimeter $2100 \mathrm{P}$ model and a $20 \mathrm{~cm}$ diameter Secchi disk, respectively.

\section{Laboratory work}

The filtered water samples were stored at 4 ${ }^{\circ} \mathrm{C}$ before analysis. Fluorescence readings for chlorophyll $a$ were taken using a Fluorometer before and after acidifying the sample residues with $0.1 \mathrm{~N} \mathrm{HCl}$. The absorbance readings were then converted into concentrations as chlorophyll $a$ using the formula according to McIntyre (2004 unpublished data):

Chl $a\left(\mu \mathrm{g}^{-1}\right)=0.003 \times\left(\mathrm{F}_{\text {before acid }}-\mathrm{F}_{\text {after acid }}\right) \times$ Ethanol Extraction Volume $(\mathrm{ml}) /$ Volume of Filtered Water (L)

where: $\mathrm{F}$ is the Fluorescence of the sample, which is equivalent to the absorbance on a Spectrophotometer and Chl $a$ is Chlorophyll $a$ in $\mu \mathrm{g} 1^{-1}$.

Unfiltered water samples were tested for alkalinity using a titrimetric method with $0.1 \mathrm{~N} \mathrm{HCl}$ and results expressed as $\mathrm{HCO}_{3}{ }^{-}$ $\left(\mathrm{mg} \mathrm{l}^{-1}\right)$ as explained by APHA et al. (1998). Nutrients including $\mathrm{SiO}_{2}, \mathrm{NO}_{3}^{-}, \mathrm{PO}_{4}^{3-}$ and $\mathrm{Fe}^{2+}$ were determined from the filtered water samples using a HACH Spectrophotometer DR/2010 model according to HACH (2002).

\section{RESULTS AND DISCUSSION}

\section{Turbidity}

The mean turbidity values ranged from 2.1 to $23.5 \mathrm{NTU}$ throughout the sampling sites and increased with depth at the sites attributing to increased suspended sediments in water due to anthropogenic activities in

The reciprocal relationship between chlorophyll $a$ and turbidity was observed at the Malagarasi River Delta implying that turbidity at this site is mainly a function of suspended sediments.

\section{Dissolved Oxygen}

The mean concentration of dissolved oxygen varied from 0.02 to $9.16 \mathrm{mg} \mathrm{l}^{-1}$ as measured at the sampling sites. Higher levels of dissolved oxygen were recorded at the water the catchment such as agriculture and pastoralism. Chlorophyll $a$ decreased with depth suggesting that turbidity is primarily a function of increased suspended sediments and bioturbation of clayed riverbed. The low secchi transparency measured at the KasuluKibondo Bridge along the Malagarasi River as compared to the rest of the sampling sites supports the observed turbidity profile.

The mean variation of chlorophyll $a$ with turbidity shows a strong positive correlation (Fig. 2). This indicates that the observed trend of turbidity at some sites is a consequence of increased phytoplankton abundance complementing the sediments surface and decreased with depth. This may be attributed to increased photosynthetic activities of algae at the water surface.

However, the low oxygen levels recorded at the bottom at these sites according to Wetzel (2001) may be attributed to oxidation of organic matter especially at the sedimentwater interface. According to Horne and Goldman (1994) the organic matter may have originated from non point sources, such as dead leaves and animal excreta. 


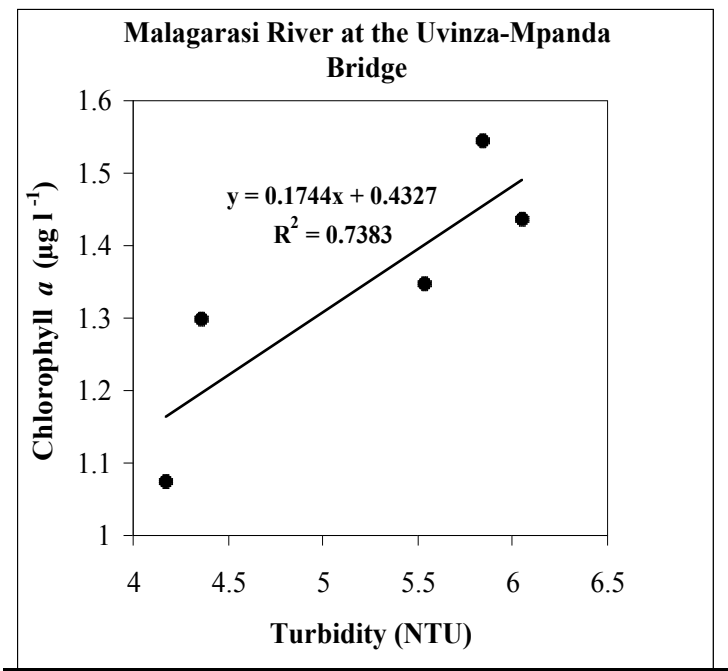

Figure 2: Mean variation of chlorophyll $a\left(\mu \mathrm{g}^{-1}\right)$ with turbidity (NTU) at the Uvinza- Mpanda Bridge

The mean variation of dissolved oxygen concentration increases with chlorophyll $a$ at most sampling sites and are both strongly correlated as shown on the Malagarasi River at Delta (Fig. 3). This observation supports

$$
\text { Light Energy }+6 \mathrm{CO}_{2}+6 \mathrm{H}_{2} \mathrm{O}-\mathrm{C}_{6} \mathrm{H}_{12} \mathrm{O}_{6}+6 \mathrm{O}_{2}
$$

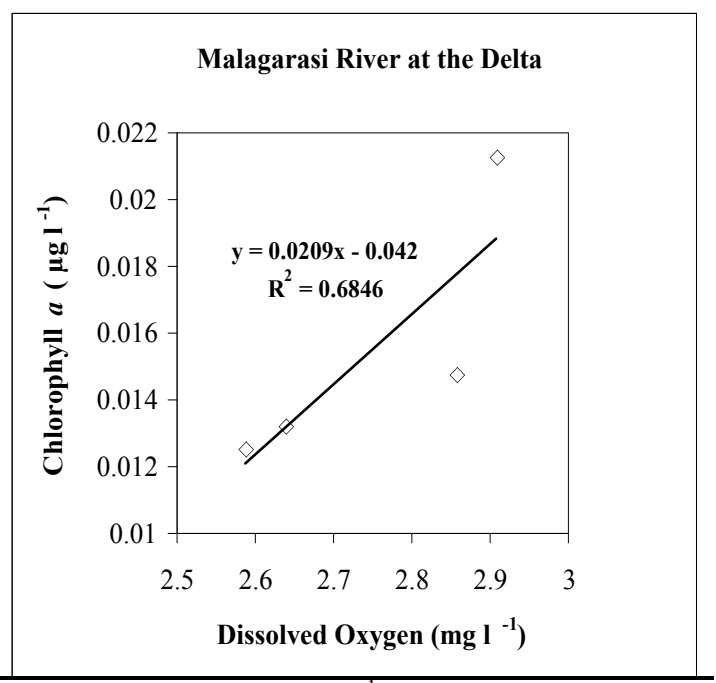

Figure 3: Mean variation of chlorophyll $a\left(\mu \mathrm{g} \mathrm{l}^{-1}\right)$ with dissolved oxygen $\left(\mathrm{mg} \mathrm{l}^{-1}\right)$ at Malagarasi River Delta 
The orthorgrade oxygen profiles were observed on the Malagarasi River e.g. Igamba Water Fall. This is probably due to the geomorphology of the river governed by the presence of high waterfall gradient of about $20 \mathrm{~m}$. The $\mathrm{pH}$ values ranged from 6.34 to 9.0 at the sampling sites and increased with increasing depth inferring to increased photosynthetic activity with depth thus supporting the observed oxygen profile.

The observed $\mathrm{pH}$ values are supported by values of $\mathrm{HCO}_{3}{ }^{-}$(18.3 to $140.3 \mathrm{mg} \mathrm{l}$ ) that increased with depth. This is probably due to increasing $\mathrm{CO}_{2}$ consumption with depth.

\section{Temperature}

The mean temperature variation with depth ranged from 20.23 to $27.28{ }^{\circ} \mathrm{C}$ with the minimum temperature observed on the Lugufu River at Jackobsen's Farm and the maximum observed on Lake Sagara at Amerika. These observations may be consequent to presence of dense vegetation cover and openness that provides and denies shade to the water surface respectively.

The temperature-decreasing trend with depth was recorded at the sampling sites e.g. Igamba Water Fall. Horne and Goldman (1994) and Cohen (2003) explain this phenomenon as a consequence of decreasing light intensity with depth from the water surface.

However, an increasing trend of the mean temperature with depth from water surface was observed on the Malagarasi River at the Kasulu-Kibondo and at the Nyanza Salt Mine. This is consequent to terrestrial heat resulting from absorption of significant solar radiation by sediments and slowly releasing it to the overlying water column.

At very shallow depth sites such as Makere River at the Kasulu-Kibondo Bridge, temperature was more-or-less the same throughout the water column. This is due to the fact that solar radiation penetrates down to the riverbed causing a uniform distribution of heat from the surface to the riverbed.

\section{Electrical Conductivity}

Electrical conductivity values ranged from 32.0 to $544.0 \mu \mathrm{S} \mathrm{cm}$. The highest measured salinity may be attributed to the observed brine leakages into the river as artisanal salt works are noted to be operating about a kilometre upstream of the bridge at Uvinza. In addition, the pore-surface water mixing effects could also be attributing to high salinity values.

However, salinity increased with depth at some sites attributing to increased dissolved ions at higher depths promoted by favourable redox conditions. Furthermore, the salinity of water decreased with depth at the sampling sites as a consequence of increased autotrophs that take up ions for use in photosynthesis at low light levels as indicated by low secchi transparency at these sites. Similarly according to Wetzel and Likens (1990), the adsorption of ions on the sediments may also significantly contribute to the decreased salinity with depth.

\section{Silica}

The mean variation of silica concentration with depth ranges from 2.7 to $35.3 \mathrm{mg} \mathrm{l}^{-1}$ for the entire sub-catchment at the sampling sites and decreases with depth at most sites. The decrease of silica with depth at these sites may be attributed to increased primary productivity as diatoms use silica for building up their cell walls.

The observed decrease of silica is supported by the strong positive correlation between silica and chlorophyll $a$ as shown at the Igamba Water Fall (Fig. 4). This implies that the observed silica concentration may predominantly be biogenic at these sites.

However, at some sites, the mean concentration of silica shows a weak negative correlation with chlorophyll $a$ implying that at these sites silica 


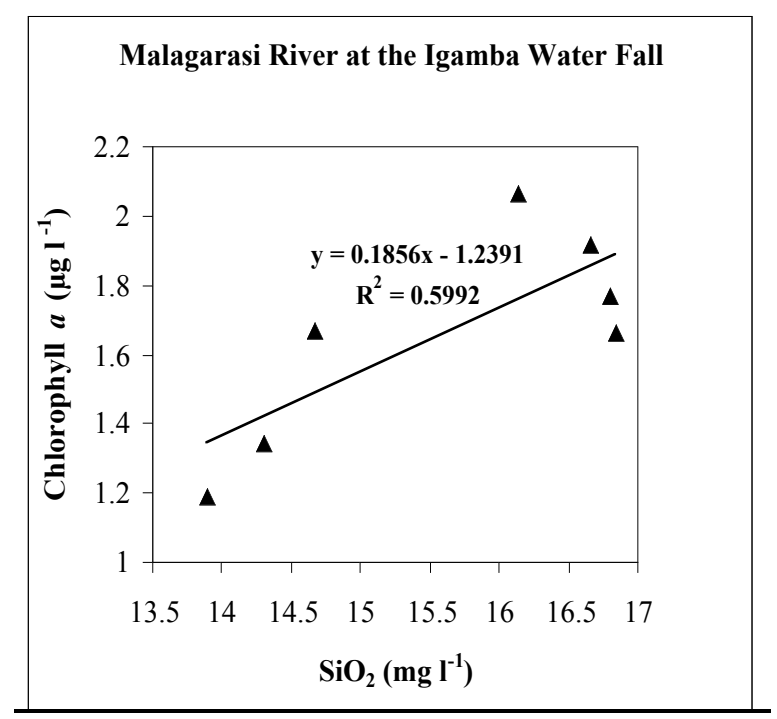

Figure 4: $\quad$ Mean variation of chlorophyll $a\left(\mu g \mathrm{l}^{-1}\right)$ with $\mathrm{SiO}_{2}\left(\mathrm{mg} \mathrm{l}^{-1}\right)$ for Malagarasi River at Igamba Water Fall

\section{Nitrate}

The mean variation of nitrate concentration with depth ranged from 0.4 to $2.6 \mathrm{mg} \mathrm{l}^{-1}$. Higher concentrations determined suggest the wide use of fertilizers on the farms along the lake, dam and riverbanks. In addition increased pastoralism may attribute to the observed levels of nitrate concentration.
At sites including the Malagarasi River Delta, Uvinza-Nguruka Bridge and KasuluKibondo Bridge along with the Igombe Dam in Tabora nitrate concentration decreased with depth as demonstrated on figure 5. This may, according to Appelo and Postma (1994), be attributed to decomposition of organic matter or increased ferrous iron as shown in the following chemical reaction:

$$
10 \mathrm{Fe}^{2+}+2 \mathrm{NO}_{3}^{-}+14 \mathrm{H}_{2} \mathrm{O} \rightarrow 10 \mathrm{FeOOH}+\mathrm{N}_{2}+18 \mathrm{H}^{+}
$$

resulting in the promotion of denitrification process.

However, at most sites the mean concentration of nitrate was observed to increase with depth. This indicates the sediment-water interface disturbance through bioturbation process and bottom currents at these sites which promote nitrate diffusion process from the sediment pore waters into the overlying water column. 


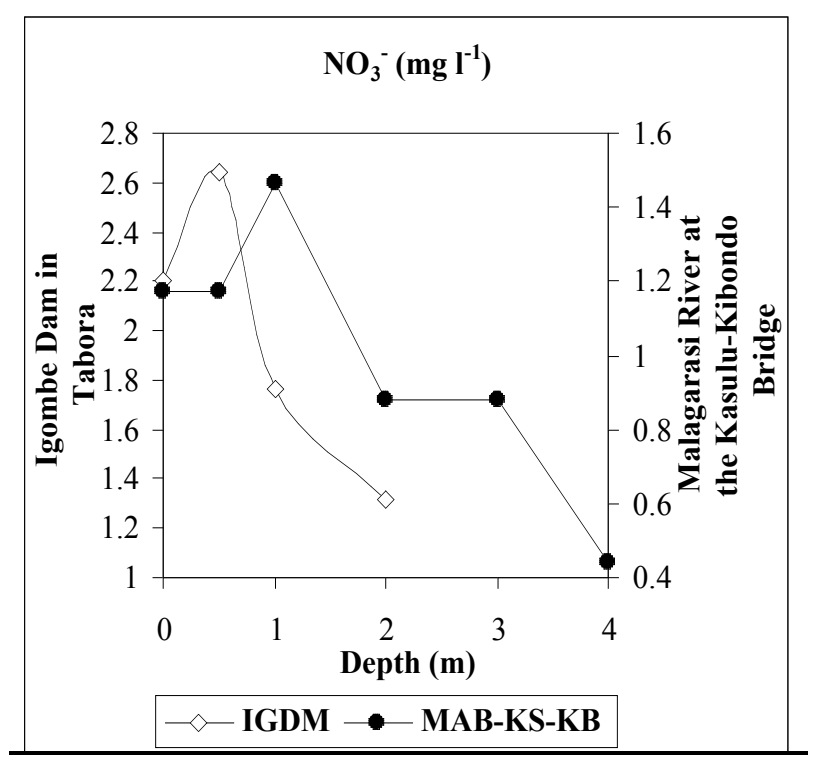

Figure 5: Mean variation of $\mathrm{NO}_{3}^{-}\left(\mathrm{mg} \mathrm{l}^{-1}\right)$ with depth $(\mathrm{m})$ at the Igombe Dam in Tabora and Malagarasi River at the Kasulu-Kibondo Bridge

\section{Phosphate}

The mean phosphate concentration varied with depth and ranges from 0.01 to $0.16 \mathrm{mg}$ $1^{-1}$ at the sampling sites with the highest values at the Igombe River as determined at
Mtega in Kaliua and in Lake Sagara at Amerika. High values of phosphate may be inferred to increased anthropogenic activities within the sub catchment.

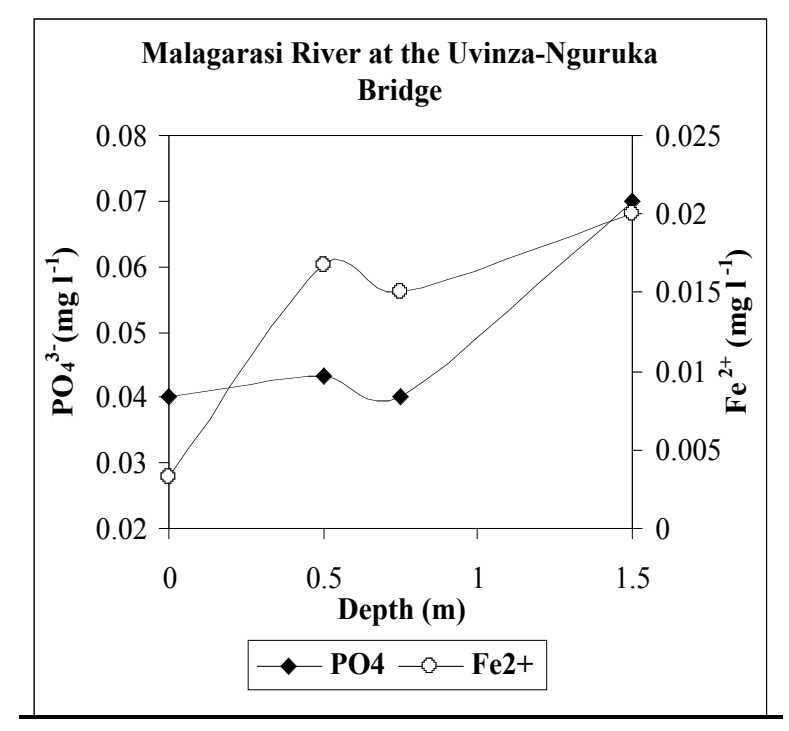

Figure 6: Mean variation of $\mathrm{PO}_{4}{ }^{3-}\left(\mathrm{mg} \mathrm{l}^{-1}\right)$ with $\mathrm{Fe}^{2+}\left(\mathrm{mg} \mathrm{l}^{-1}\right)$ at the Uvinza-Nguruka Bridge 
At most sites the mean concentration of phosphate decreased with increasing depth from the water surface. This is attributed to adsorption of phosphate on to sediments enriched with ferric oxides and or ferrous hydroxide depending on the field stability conditions prevailing there.

However, the mean concentrations of ferrous $\left(\mathrm{Fe}^{2+}\right)$ iron and phosphate $\left(\mathrm{PO}_{4}{ }^{3-}\right)$ were noted to increase with depth at some sites including the Uvinza-Nguruka Bridge (Fig. 6). This is possibly due to decomplexation of iron phosphate complex through reduction process.

According to Wetzel (2001), these observations may be attributed to reducing conditions. Redox potential and $\mathrm{pH}$ correlated negatively thus supporting the field stability of ferrous $\left(\mathrm{Fe}^{2+}\right)$ iron.

\section{CONCLUSIONS}

The data from the present study show significant changes in concentrations of limnological parameters among the 20 sampled sites within the Lake Tanganyika sub catchment. The depths and widths of rivers, lakes and the dam vary from one point to another due to anthropogenic activities which result in high siltation and erosion.

From these data we conclude also that, several processes such as dissolution, diffusion, nitrification, denitrification, reduction, absorption and adsorption along with mixing control the levels of abiotic parameters in the entire sub catchment.

Future research work is recommended to focus on the quantification of flow, sediment load and nutrient budget at various points along the rivers, lakes and the dam in both dry and rain seasons in order to fully understand the limnological functioning of the Lake Tanganyika sub catchment.

\section{ACKNOWLEDGEMENTS}

The Royal Geographical Society (UK) and the US National Geographical Society (NGS) funded this work. We are grateful to the University of Dar es Salaam and the Ministry of Natural Resources and Tourism for the permission to conduct this work. The Kigoma and Tabora regions authorities are thanked for their support. The Tanzania Fisheries Research Institute (TAFIRI), the Nyanza Project and the support staff are greatly acknowledged for their assistance and cooperation.

\section{REFERENCES}

APHA, AWWA and WEF 1998 Standard Methods for Examination of Water and Wastewater. $20^{\text {th }}$ ed. American Public Health Association. Washington, DC.

Appelo CAJ and Postma D 1994 Geochemistry, groundwater and pollution. $2^{\text {nd }}$ ed. A.A. Balkema. Rotterdam. The Netherlands. 536pp.

Cohen AS 2003 Paleolimnology: The History and Evolution of Lake Systems. Oxford University Press. Inc. New York. 500pp.

HACH Company 2002 Water Analysis Handbook. $4^{\text {th }}$ ed. Loveland. Colorado. USA. $1260 \mathrm{pp}$.

Horne AJ and Goldman CR 1994 Limnology. $2^{\text {nd }}$ ed. McGraw-Hill. Inc. USA. 576pp.

Langenberg VT, Nyamushashu S, Roijackers R and Koelmans AA 2003 External Nutrient Sources for Lake Tanganyika. Internat. Assoc. Great Lakes Res., J.Great Lakes Res. 29 (2): 169-180.

Nkotagu HH and Ndaro SGM (eds.) 2004 The Malagarasi Wetland Ecosystem. Dar es Salaam University Press. 141pp.

Wetzel RG and Likens GE 1990 Limnological Analyses. $2^{\text {nd }}$ ed. SpringerVerlag. New York. 391pp.

Wetzel RG 2001 Limnology: Lake and River Ecosystems. $3^{\text {rd }}$ ed. Academic Press. 1006pp. 